\title{
Inventory Management and SMEs Profitability. A Study of Furniture Manufacturing, Wholesale and Eatery Industry in Delta State, Nigeria
}

\author{
Otuya Sunday* ${ }^{*}$ Eginiwin E. Joseph \\ Department of Accounting \& Finance, Faculty of Humanities, Social and Management Sciences, Edwin Clark University, \\ Kiagbodo, Delta State \\ *Corresponding author: otuya.sunday@gmail.com
}

\begin{abstract}
Inventory constitutes bulk of current assets small and medium scale enterprises (SMEs) such as bakeries, fast food/eateries, chain stores and furniture making firms. SMEs need to understand the true costs associated with inventory management and poor inventory productivity so as to be able to review the benefits of alternative approaches. The objective of the study was to examine the effect of inventory management on profitability of SMEs in Nigeria. The study used a descriptive research design. The population consists of all SMEs operating in Delta State. The study used stratified random sampling. 10 SMEs were randomly selected from each stratum making a total of 30 firms for the study. Data for the study were obtained through the administration of a self-designed questionnaire to managers or accountants of the sampled firms. The questionnaire was structured to elicit information about the trading and financial activities for the last two accounting years. A multiple regression analysis was conducted to test the model established for the study. Findings of the study reveal that inventory turnover has a significant positive relationship with financial performance of SMEs. The study also reveals that there is a negative relationship between inventory conversion period and profitability; and no significant positive relationship between inventory leanness and profitability. The study concludes that inventory management has a great role to play in corporate financial performance of firms hence firms' inventory systems must maintain an appropriate inventory levels to enhance profitability and reduce the inventory costs associated with holding excessive stock in the warehouses. In line with the findings of the study, it is recommended that firms should embrace modern production technology that will enhance faster production to shorten inventory conversion period which will in turn improve inventory turnover and profitability.
\end{abstract}

Keywords: inventory management, Small and Medium Sized Enterprises, profitability

Cite This Article: Otuya Sunday, and Eginiwin E. Joseph, "Inventory Management and SMEs Profitability. A Study of Furniture Manufacturing, Wholesale and Eatery Industry in Delta State, Nigeria." Journal of Finance and Accounting, vol. 5, no. 3 (2017): 75-79. doi: 10.12691/jfa-5-3-1.

\section{Introduction}

Inventories are working capital component of assets or items held in the normal course of business that will be consumed or used in the production of goods for resale. Pandey [1] defines inventory as the stocks of raw materials, work in progress, finished goods and supplies held by a company to facilitate operations in the production process. Inventory management on the other hand, is a systematic process which aims at discovering and maintaining optimum levels of investment in all types of inventories and making best use of the flow of goods, information and other related resources like people and energy from the point of origin to the point of final consumption [2].

Issues of inconsistencies of inventory levels with the resultant effects of losses that come due to over, understocking, expired stock, failure to meet targets and low morale of the company workers have raised questions for management about the efficiency of inventory management procedures in place. The task of inventory management has often been associated with either overstocking and too little management or under-stocking and too much management [3]. Each extreme has severe penalties in either direction.

Studies [3-13] acknowledge that inventory management plays an important role in every organization as any unproductive inventory system will lead to delivery delays, production disorganization or loss of customers and sales. Wanke [14] states that inventory management approaches are a function of product, operational and demand related variables such as delivery time, obsolescence, coefficient of variation of sales and inventory turnover and that logistics managers are more likely to decentralise inventory in order to stock product close to the customer's facility if the customers demand a reduced delivery time.

In traditional settings, stock of raw materials, spare parts, work in progress, components and finished goods 
are reserved as a cushion against the possibility of running out of stock items. However, in recent times, it has been discovered that keeping large buffer inventories leads to incurring inventory costs in terms of warehouse space, security personnel, insurance and the risk of deterioration and obsolescence. Consequently, corporate organisations are embracing a different approach to production and inventory management. Since early 1980s, an inventory management system which leads to inventory reduction has become the primary target, as is often the case in justin-time (JIT) systems where raw materials and parts are purchased or produced just-in-time to be used at each stage of the production process $[15,16]$.

Small and Medium Sized Enterprises play a significant role in the economic development of any nation. However, Otuya and Akporien [17] assert that in spite of their strategic importance there is still a large number of SMEs that perform poorly due to incompetent management. In recent years, SMEs have encountered numerous challenges especially in inventory management or material control, thus affecting their financial performance. There have been cases of materials overstocking which eventually get expired or out dated, under stocking, lack of stock-taking, theft of materials by workers and delays in deliveries of materials into the organizations among others $[6,17,18,19]$.

In some SMEs such as eateries, supermarkets and furniture manufacturing companies, nearly $60 \%$ to $70 \%$ of the total funds employed are tied up in current assets, of which inventory forms the most significant component $[5,8,13]$. Thus, it should be managed in order to avail the inventories at right time in right quantity. Small and Medium Scale Enterprises (SMEs) need to understand the true costs associated with inventory management and poor inventory productivity so as to be able to review the benefits of alternative approaches.

\section{Statement of Problems}

Many companies face challenges of inconsistent inventories, wrong estimate, poor reaction to customers' demand and lack of proper accounting recording systems resulting to low performance [6]. Similarly, Abdulrasheed, Khadijat, Sulu and Olanrewaju [19] observed that companies face problems of inconsistent deliveries, reduced consumer effective demand and high cost of production due to poor inventory management techniques leading to poor performance. Duru, Okpe and Udeji [18] posit that inventory is the livewire of any manufacturing firm. They maintain that because of shortage of materials to meet sudden increase in customers demand, reduction in profit margin, low returns on equity, wastages of materials, pilferage arising due to excess stock and sleep in communication chains that exist in most industries, inventory management has become mandatory on each and every manager responsible for production in an organization.

Inventory is one vital resource that any corporate organization needs. Like any other business resource, inventory is limited in supply; hence it requires effective management rather than neglect. The cost of procurement of materials (inventories) is also important on one hand, for the fact that over stocking will imply tying down capital and risk of becoming obsolete while on the other, under stocking could lead to shortages and production bottle neck. The challenge then is to determine how all these affect the financial performance of the firm. Knowledge of the optimum inventory management techniques will enable business managers to strike a balance on what quantity to buy, when and where to buy on a regular basis devoid of scarcity, how to go about the procurement and the amount to invest on inventory towards maximizing profit. This is the concern and focus of this study.

The effect of inventory management on financial performance of firms has been a subject of debate by academic scholars and corporate managers for a long time. A number of these studies have come up with divergent and mixed results [4,5]. In the developing economies of Africa and Asia [3,6,7,8,13] have also conducted some empirical studies. Eneje, Nweze and Udeh [20], Duru, Okpe and Udeji [18] have also carried out some studies in Nigeria with emphasis on Engineering firms, manufacturing and cement industries. This study departs from these previous works by placing emphasis on wholesale/superstores, fast food, eateries and furniture manufacturing firms which have rarely been used by previous researches in Nigeria. Besides, these SMEs are considered to have bulk of their working capital in inventories.

\section{Objectives of the Study}

The broad objective of the study is to examine the effect of inventory management on profitability of SMEs in Delta State. Specifically, the study seeks to:

(i) examine the relationship between inventory turnover and profitability of SMEs.

(ii) determine to what extent inventory conversion period affect profitability of SMEs.

(iii)ascertain the influence of inventory leanness on profitability of SMEs..

\section{Research Questions}

The study will provide answers to the following questions:

(i) To what extent does inventory turnover affect profitability of SMEs?

(ii) What is the relationship between inventory conversion period and profitability of SMEs?

(iii)To what extent does inventory leanness affect profitability of SMEs?

\section{Research Hypothesis}

In order to answer the research questions and achieve the research objectives, the study has postulated the following hypotheses in the null form:

Ho1: There is no significant statistical relationship between inventory turnover and profitability of SMEs. 
Ho2: There is no significant statistical relationship between inventory conversion period and profitability of SMEs.

Ho3: There is no significant statistical relationship between inventory leanness and profitability of SMEs.

\section{Methodology}

The study adopted descriptive research design. Descriptive research is a scientific method which involves observing and describing the behavior of a subject without influencing it in any way [21]. The population consists of all SMEs operating in Delta State. The study used stratified random sampling. The strata are necessary because the target population is heterogeneous in nature. The strata consisted of fast food/eateries, supermarkets and furniture making firms. 10 SMEs were randomly selected from each stratum making a total of 30 firms for the study. Data for the study were obtained by the help of three research assistants through the administration of a self-designed questionnaire to managers or accountants of the sampled firms. The questionnaire was structured to elicit information about the trading and financial activities for the last two accounting years.

Regression analysis was conducted to examine the form of relationship between dependent variable and the independent variables. To test the hypotheses developed, a liner regression model which expresses the SMEs profitability as a function of inventory management is stated in functional form as follows:

$$
P F T=f(I T, I C P, I L N)
$$

This can be written in explicit econometric form as:

$$
P F T_{i t}=\beta_{0}+\beta_{1} I T_{i t}+\beta_{2} I C P_{i t}+\beta_{3} i I L N_{i t}+e_{i t}
$$

Where:

PFT = Profitability; IT = Inventory Turnover; ICP = Inventory Conversion Period and ILN = Inventory Leanness. i represents sampled SMEs; t represents the time dimension; $\beta_{0}=$ Constant or Intercept. $\beta_{1-3}=$ Coefficients to be estimated or the Coefficients of slope parameters and $\mathrm{e}=$ Stochastic or disturbance term.

\section{Operationalization of Variables}

The table below shows the measurement of the variables:

Table 1. Measurement of Variables

\begin{tabular}{|l|l|c|c|}
\hline Variables & Measurement & $\begin{array}{c}\text { A priori } \\
\text { Sign }\end{array}$ & Notation \\
\hline Profitability & $\begin{array}{l}\text { Profitability is taken as Gross } \\
\text { Profit Margin (GPM). To be } \\
\text { measured as the gross profit } \\
\text { scaled by turnover. }\end{array}$ & + & PFT \\
\hline $\begin{array}{l}\text { Inventory } \\
\text { Turnover }\end{array}$ & $\begin{array}{l}\text { Measured as Cost of Sales } \\
\text { scaled by Inventory }\end{array}$ & + & IT \\
\hline $\begin{array}{l}\text { Inventory } \\
\text { Conversion } \\
\text { Period }\end{array}$ & $\begin{array}{l}\text { This is measured as 365 days } \\
\text { divided by inventory } \\
\text { turnover ratio. }\end{array}$ & - & ICP \\
\hline $\begin{array}{l}\text { Inventory } \\
\text { Leanness }\end{array}$ & $\begin{array}{l}\text { Measured as a percentage of } \\
\text { closing inventory on total } \\
\text { asset }\end{array}$ & - & ILN \\
\hline
\end{tabular}

\section{Data Presentation and Analysis}

Table 2. Descriptive Statistics for the Variables

\begin{tabular}{|l|c|c|c|c|}
\hline & GPM & IT & ICP & ILN \\
\hline Mean & 20.90000 & 19.08333 & 24.36667 & 33.33333 \\
\hline Median & 19.55000 & 18.25000 & 18.00000 & 32.50000 \\
\hline Maximum & 34.40000 & 47.40000 & 56.00000 & 67.00000 \\
\hline Minimum & -11.80000 & 6.500000 & 17.00000 & 16.00000 \\
\hline Std. Dev. & 8.903080 & 11.33609 & 13.07138 & 13.49670 \\
\hline Skewness & -1.425545 & 1.405804 & 0.815505 & 0.862255 \\
\hline Kurtosis & 7.157843 & 5.223654 & 2.442479 & 3.462049 \\
\hline Jarque-Bera & 31.77046 & 16.06222 & 3.713780 & 3.984278 \\
\hline Probability & 0.000000 & 0.000325 & 0.000000 & 0.136403 \\
\hline Sum & 627.0000 & 572.5000 & 731.0000 & 1000.000 \\
\hline Sum Sq. Dev. & 2298.680 & 3726.702 & 4954.967 & 5282.667 \\
\hline Observations & 30 & 30 & 30 & 30 \\
\hline
\end{tabular}

Source: An extract from the result output analyzed with E-View 7.0 KEYS: GPM = Gross Profit Margin; IT= Inventory Turnover; ICP = Inventory Conversion Period; ILN = Inventory Leanness

The above displays the descriptive statistics for the data. The descriptive statistics considered were minimum, maximum, mean and standard deviation, Jarque-Bera along with their probability values. The GPM has a mean of 20.9 percent. The minimum and maximum values are 11.8 and 34 percent respectively with a standard deviation of 8.9. The standard deviation measuring the spread of the distribution is low and indicates considerable dispersion from the mean and that the distribution is inclusive of SMEs with significant variations in their profitability level. The Jarque-Bera stood at 31.77 with a p-value of 0.000 which indicate that the data satisfies normality.

Further, IT and ICP have mean values of 19 and 24 respectively. The implication is that on the average, sampled firms turn over the inventory about 19 times in any year. It also means that it takes about 24 day to convert stock from raw materials to finished goods for sale. The statistics also shows that the IT and ICP have minimum values of 6 and 17 respectively. The maximum values for the variables also recorded 47 and 56 . The standard deviation also stood at 11 and 7 . The standard deviation for IT is large indicating that there is not much deviation among the SMEs sampled in terms of number of days stock is turned over. However, the standard deviation for ICP is low compared to the mean value which means that there is significant variations in the number of days SMEs in the study hold stock. The Jarque-Bera values of 16 and 13 for IT and ICP respectively along with their probability values of 0.0000 indicates that the data satisfies normality and suitable for further regression analysis.

The descriptive statistics of the firms' Inventory Leanness as indicated in table shows that the mean proportion of the inventory leanness was 33.3 percent. Results from the table further indicate a maximum and minimum of 67 and 16 percent respectively. The standard deviation o 13 percent also shows a significant disparity among the SMEs in volume of inventory as a percentage of total assets of the firm. The Jarque-Bera value of 3.9 
with a p-values of $0.13(\mathrm{p}>0.05)$ indicate that the distribution fails the normality test $(\mathrm{p}<0.05)$. The analysis of the descriptive statistics indicates that all the variables except Inventory leanness satisfy the normality criterion as their respective Jarque-Beras were all significant and the p-values less than the 5\% significant level.

Table 3. Correlation of the Variables

\begin{tabular}{|c|c|c|c|c|}
\hline & GPM & IT & ICP & ILN \\
\hline GPM & 1.000000 & & & \\
\hline IT & 0.035868 & 1.000000 & & \\
\hline ICP & -0.071084 & -0.259663 & 1.000000 & \\
\hline ILN & 0.010733 & 0.271888 & -0.272989 & 1.000000 \\
\hline
\end{tabular}

Source: An extract from the result output analyzed with E-View 7.0 KEYS: GPM = Gross Profit Margin; IT= Inventory Turnover; ICP = Inventory Conversion Period; ILN = Inventory Leanness

The table shows the relationship among the variables. GPM is observed to correlate positively with ILN $(\mathrm{r}=0.0107)$. This implies that increase in inventory by $1.07 \%$, will bring about a unit growth gross profit margin of small businesses. The correlation also shows that GPM has a negative relationship with IT $(\mathrm{r}=-0.0358)$ and ICP $(\mathrm{r}=-0.0710)$. The implication of this is that as inventory turnover rates and inventory conversion period grow by $3.5 \%$ and 7 days respectively, the gross profit margin of SMEs shrinks by $1 \%$.

Further, the table also indicates that IT is positively correlated with ILN ( $\mathrm{r}=0.0271$ but negatively correlated with ICP $(\mathrm{r}=-0.259)$. It implies that increase in inventory turnover increases leanness by about 3\% whereas higher inventory turnover reduces inventory conversion period by $2.59 \%$. ICP is also observed to have a negative relationship with ILN ( $\mathrm{r}=-0.0272)$ implying that increase in inventory leanness will reduce period stock is held by about 3 days. As shown in table, none of the variables is strongly correlated with each other $(r>0.8)$.

Table 4. Regression Statistics for the Model

\begin{tabular}{|c|c|c|c|c|}
\hline $\begin{array}{l}\text { Dependent Variable: GPM } \\
\text { Method: Least Squares } \\
\text { Sample: } 1 \text { - } 30 \\
\text { Included observations: } 30\end{array}$ & & & & \\
\hline Variable & Coefficient & Std. Error & t-Statistic & Prob. \\
\hline $\mathrm{C}$ & 23.77321 & 5.397219 & 4.404714 & 0.0002 \\
\hline IT & 0.116768 & 0.123834 & 0.942937 & 0.0019 \\
\hline ICP & -0.095848 & 0.104408 & -0.918016 & 0.0070 \\
\hline ILN & 0.092360 & 0.107429 & 0.351398 & 0.5861 \\
\hline $\begin{array}{l}\text { R-squared } \\
\text { Adjusted R-squared } \\
\text { S.E. of regression } \\
\text { Sum squared resid } \\
\text { Log likelihood } \\
\text { F-statistic }\end{array}$ & $\begin{array}{c}0.617011 \\
0.415128 \\
7.127437 \\
1320.809 \\
-99.34019 \\
1.148479\end{array}$ & \multicolumn{2}{|c|}{$\begin{array}{c}\text { Mean dependent var } \\
\text { S.D. dependent var } \\
\text { Akaike info criterion } \\
\text { Schwarz criterion } \\
\text { Hannan-Quinn criter. } \\
\text { Durbin-Watson stat }\end{array}$} & $\begin{array}{l}19.79333 \\
7.181967 \\
6.889346 \\
7.076173 \\
6.949114 \\
2.540702 \\
\end{array}$ \\
\hline Prob(F-statistic) & 0.000035 & & & \\
\hline
\end{tabular}

Source: An extract from the result output analyzed with E-View 7.0

KEYS: GPM = Gross Profit Margin; IT= Inventory Turnover; ICP = Inventory Conversion Period; ILN = Inventory Leanness.

The summarized regression results in the table show that the multiple regression models is highly significant with $\mathrm{R}^{2}$ value of 0.617 meaning that $61.7 \%$ of the variation in the dependent variable (gross profit margin) is explained by the independent variables while $38.3 \%$ is explained by other variables outside the model. Also, the F-Stat of 1.14 shows that the predictor variables are very significantly related with the response variables.

\section{Discussion of Findings}

The aim of this study is to examine the effect of inventory management on profitability of SMEs in Nigeria. In discussing the results, the ordinary least squares regression estimates are utilized to examine the relationship between inventory management and financial performance of 30 SMEs in Delta State. This study utilizes several measures as proxies for inventory management. Findings of the study are discussed below:

\section{Inventory Turnover and Profitability}

The regression estimation reveals that a significant positive relationship exists between IT and GPM $(\mathrm{t}=0.9429, \mathrm{p}=0.0019<0.05)$. We therefore use this as some evidence to empirically state that inventory turnover has an effect on companies' financial performance, and hence we reject the null hypothesis and accept the alternative hypothesis. The implication is that small businesses that have higher inventory turnover tend to have better performance than those with lower inventory turnover. This result meets our a priori expectation and is consistent with findings of $[22,23]$. However, this finding does not conform to Sitienei and Memba, [24].

\section{Inventory Conversion Period and Profitability}

Findings from this study reveal an insignificant negative relationship between inventory conversion period and financial performance of brewery firms in Nigeria $((t=-0.958, p=0.0070<0.05)$. This implies that the longer days it takes SMEs to turn raw materials purchased into finished goods and sold to customers the lesser profits the firm will make. The result meets our a priori expectation and consistent with previous studies such as Gamze, Ahmet and Emin [10], Mogaka and Jagongo [25], Reyhani [26] and Sitienei and Memba [24]. 


\section{Inventory Leanness and Profitability}

The regression estimation reveals no significant positive relationship between ILN and GPM ( $\mathrm{t}=0.9236$, $\mathrm{p}=0.586>0.05$ ). This implies that level of closing stock in the warehouse as at the end of a company's financial year does not really affect the financial performance of the firm. This did not meet our a priori expectation. This result does not conform to previous studies such as Koumanakos [4] and Eroglu and Hofer [27].

\section{Conclusion and Recommendation}

We have analyzed some simple descriptive statistics and we have used regressions and econometrical approaches, to verify whether inventory management impacts on the financial performance of SMEs in Nigeria. The study, using the results of the inventory management statistics and exploratory variables in a regression model showed that inventory turnover has a significant positive relationship with financial performance of SMEs in Nigeria during the period under review. The study also reveals that there is a negative relationship between inventory conversion period and profitability; and no significant positive relationship between inventory leanness and profitability. The study concludes that inventory management has a great role to play in corporate financial performance of firms hence firms' inventory systems must maintain an appropriate inventory levels to enhance profitability and reduce the inventory costs associated with holding excessive stock in the warehouses. In line with the findings of the study, it is recommended that firms should embrace modern production technology that will enhance faster production to shorten inventory conversion period which will in turn improve inventory turnover and profitability.

\section{References}

[1] Pandey, I. M. (2005). Financial Management. New Delhi: Vikas Publishing House PVT Ltd.

[2] Green, R. \& James, H. (2000). Production and Inventory Control Handbook, (3rd edition). New York, McGraw- Hill.

[3] Sitienei, W. \& Memba, F. (2016). The effect of inventory management on profitability of cement manufacturing companies in Kenya: A case study of listed cement manufacturing companies in Kenya. International Journal of Management and Commerce Innovations, 3(2), 111-119.

[4] Koumanakos, D.P. (2008). The effect of inventory management on firm performance. International Journal of Productivity and Performance Management, 57, 355-369.

[5] Juan, P. G., and Martinez, S. (2002). Effects of working capital management on SME profitability, Journal of Business Finance \& Accounting, 30 (3-4), 1-14. Retrieved from http://www.sagepublications

[6] Mohamad, S. J., Suraidi, N.N., Rahman, N.N.S. \& Suhaimi,R.D.S (2016). A Study on relationship between inventory management and company performance: A case study of textile chain store. Journal of Advanced Management Science, 4(4), 299-304.

[7] Prempeh, K.B. (2015). The impact of efficient inventory management on profitability: evidence from selected manufacturing firms in Ghana. MPRA Paper No. 67889. Available online at https://mpra.ub.uni-muenchen.de/67889/.

[8] Mukopi, C.M. \& Iravo, A.M. (2015). An analysis of the effects of inventory management on the performance of the procurement function of sugar manufacturing companies in the Western Kenya Sugar Belt. International Journal of Scientific and Research Publications, 5(5), 2-14.

[9] Vedran, C., Ari-Pekka, H, \& Weiss, L. (2009). On the relationship between inventory and financial performance in manufacturing companies. International Journal of Operations \& Production Management, 29(8), 789-806.

[10] Gamze, V., Ahmet, H., \& Emin, H. VC (2012). Effects of working capital on firm's performance: Evidence from Turkey. International Journal of Economics and Financial Issues, 2(4), 2012, 488-495.

[11] Kimaiyo, K.K., \& Ochiri, G. (2014). Role of inventory management on performance of manufacturing firms in Kenya - a case of new Kenya Cooperative Creameries. European Journal of Business Management, 2(1), 336-341.

[12] Sahari, S., Tinggi, M. \& Kadri, N. (2012). Inventory management in Malaysian construction firms: Impact on performance. SIU Journal of Management, 2 (1), 59-72.

[13] Mwangi, W., \& Nyambura, M.T. (2015). The role of inventory management on performance of food processing companies: a case study of Crown Foods Limited Kenya. European Journal of Business and Social Sciences, 4(04), 64-78.

[14] Wanke., D. (2000). Saunders, strategic purchasing and supply management. Pitman Journal of Monetary, Economics, 14, 71-96.

[15] Abdulraheem, A., Yahaya, K.A., Isiaka, S.B., \& Aliu, O. A. (2011). Inventory management in small business finance. Empirical evidence from Kwara State, Nigeria. British Journal of Economics, Finance and Management Sciences, 2(1), 49-57.

[16] Sekeroglu, G. \& Altan M. (2014). The Relationship between inventory management and profitability: a comparative research on Turkish firms operated in weaving industry, eatables industry, wholesale and retail industry. International Journal of Social, Management, Economics and Business Engineering, 8(6), 1665-1670.

[17] Otuya, S., \& Akporien, F. (2017). Fraud risk management and sustainability of SMEs in Nigeria. International Journal of Innovative Research and Advanced Studies, 4(9), 11-25.

[18] Duru, A. N., Okpe, I. \& Udeji, A. O. (2014). Inventory positioning and firm performance in engineering companies. Evidence from Nigeria. World Engineering \& Applied Sciences Journal 5 (3), 85-91

[19] Abdulrasheed, A.R, Khadijat, A., Sulu, B.I. \& Olanrewaju, A.A. (2013). Inventory management in small business. Department of Accounting and Finance, University of Ilorin. Journal Publication 6(1), 163-167.

[20] Eneje, C., Nweze, A. \& Udeh, A. (2012). Effect of efficient inventory management on profitability: Evidence from selected brewery firms in Nigeria. International Journal of Current Research, 4, 350-354.

[21] Simon, M.K. \& Goes, J. (2013). Dissertation and Scholarly Research: Recipe for Success. Seatle, W.A: Dissertations Success LLC.

[22] Moridipour, H. \& Mousavi, Z. (2016). Relationship between inventory turnover with gross profit margin and sales shocks. International Research Journal of Applied and Basic Sciences, 8 (8), 1106-1109.

[23] Kolias, G. D., Dimelis S. P. \& Filios, V. P. (2010). An empirical analysis of inventory turnover behavior in Greek retail sector. International Journal on Production Economics, 133, 143-153

[24] Sitienei, W. \& Memba, F. (2016). The effect of inventory management on profitability of cement manufacturing companies in Kenya: A case study of listed cement manufacturing companies in Kenya. International Journal of Management and Commerce Innovations, 3(2), 111-119.

[25] Mogaka, M. and Jagongo, P. (2013). Working capital management and firm profitability: empirical evidence from manufacturing and construction firms listed on Nairobi Securities Exchange, Kenya. International Journal of Accounting and Taxation, 1(1), 1-14.

[26] Rehn, E. (2012). Effects of working capital management on company's profitability. MSc Thesis submitted to Hanken School of Economics. Retrieved online July 11, 2017 from https:/helda.helsinki.fi/bitstream/handle/10138/32507/rehn.pdf.

[27] Eroglu, C. \& Hofer, C. (2011). Lean, leaner, too lean? The inventory-performance link revisited. Journal of Operations Management, 29, 356-369. 